Dr Ivana Đorđev

Eldena Stanić ${ }^{2}$

Visoka škola strukovnih studija za vaspitače „Mihailo Palov”

Vršac
Original scientific paper

UDC: 37.016:81-028.31

DOI: $10.5937 /$ istrped2001076D

\title{
KONCEPTUALIZACIJA SRPSKOGA JEZIKA U MULTINACIONALNOJ STUDENTSKOJ ZAJEDNICI
}

Rezime: Cilj ovoga rada jeste da se primenom teorijsko-metodološkog aparata kognitivne lingvistike otkrije kako studenti kojima je maternji jezik srpski/rumunski/romski doživljavaju većinski, jezik sredine - srpski jezik. S jedne strane, razmatrani su stavovi studenata čiji je maternji jezik srpski, i, uporedo s tim, stavovi studenata kojima je srpski nematernji jezik. Kada je za to bilo razloga, dat je i osvrt na razliku u konceptima između studenata prvog i drugog nivoa studija. Pažnja je posebno posvećena osvetljavanju vladajućih koncepata kada je reč o negovanju srpskoga jezika, ortografije, kao i unapređivanju visokoškolske nastave ovoga predmeta. Primarna hipoteza od kojih smo u analizi nakon određivanja ciljeva rada pošli jeste da otkrivanje i detaljnije proučavanje vladajućih koncepata studenata o srpskom jeziku identifikuje polja u kojima treba unaprediti nastavu ovoga jezika. Rezultati istraživanja sprovedenog školske 2019/2020. godine sa studentima Visoke škole strukovnih studija za vaspitače „Mihailo Palov” u Vršcu - jedinstvene u Evropi po tome što se u njoj nastava realizuje na tri jezika: srpskom, rumunskom i romskom - pokazali su da se srpski jezik iz perspektive studenata doživljava kao kompleksan pojam; da aktivnostima eksplicitno usmerenim na usavršavanje/negovanje ovoga jezika studenti posvećuju isto koliko i učenju stranoga jezika - dnevno najduže jedan školski čas, a da bi unapredili poznavanje srpskog jezika najčešće koriste internet $\mathrm{i}$ druge elektronske izvore. Pri tome, studenti kojima je maternji jezik srpski jezik ističu važnost negovanja kulture govora i upotrebe lepih reči, dok studenti kojima je srpski nematernji jezik izdvajaju problem (mnoštva) pravopisnih grešaka u pismenom izražavanju. Kada je reč o mogućnostima unapređivanja nastave srpskoga jezika u multikulturalnom okruženju kakva je sredina u kojoj je vršeno istraživanje, studenti smatraju da je presudna uloga kvantiteta, odnosno da nastavi srpskog jezika treba posvetiti više časova predavanja, vežbi, ali i seminara, kao i dopunskog rada. Dobijeni rezultati potvrdili su polaznu hipotezu i dali neophodne smernice za unapređivanja nastave srpskoga (kao maternjeg i kao nematernjeg) jezika.

Ključne reči: nastavna praksa, pojmovne metafore, primenjena kognitivna lingvistika, srpski jezik kao maternji i kao nematernji jezik, studenti.

\footnotetext{
${ }^{1}$ ivanacurcin@yahoo.com

²eldena.stanic@gmail.com
} 


\section{Uvod}

Članovi jedne govorne zajednice uspešno komuniciraju upravo zahvaljujući tome što govoreći i razumevajući svoj jezik „vide” u osnovi iste stvari (Klikovac, 2018: 261); ,jezik [...] živi u glavama svojih korisnika; a u njima živi velikim delom u vidu mentalnih slika" (ibidem, 269). One nisu proizvoljne niti individualne, nego su rezultat iskustva koji postoji u jednoj zajednici i konvencija karakterističnih za određeni jezik (ibidem, 261).

Srpski jezik, koji je u fokusu interesovanja ovoga rada, u Republici Srbiji uči se kao maternji jezik i kao nematernji jezik; predškolsko, osnovno i srednje obrazovanje moguće je završiti na srpskom jeziku, ali i na jednom od zvaničnih jezika nacionalnih manjina. Nastava srpskog jezika kao nematernjeg odvija se, prema podacima nacionalnih saveta nacionalnih manjina, u 88 osnovnih i 20 srednjih škola (prema: Krajišnik i Strižak, 2018: 182), dok (v. čl. 80 Zakona o visokom obrazovanju ${ }^{3}$ ) visokoškolske ustanove mogu omogućiti polaganje ispita, izvoditi pojedine delove studija i organizovati izradu i odbranu završnog rada na jeziku nacionalne manjine i na stranom jeziku, u skladu sa svojim statutom (studijski program na jeziku nacionalne manjine ili na stranom jeziku se može ostvarivati ukoliko je takav program akreditovan). Primer potonjeg jeste Visoka škola strukovnih studija za vaspitače „Mihailo Palov" u Vršcu, koja je jedina akreditovana visokoškolska ustanova u regionu, pa i šire, gde se nastava, izvodi na srpskom, rumunskom i od 2009. godine i na romskom jeziku.

Osvešćujući da smo u „svakom trenutku svoga svesnog postojanja mi okruženi jezikom i u njega uronjeni" (Bugarski, 2003: 11), nema prirodnije stvari nego da za trenutak zastanemo, zapitamo se i istražimo kako mislimo reči srpski jezik, da otkrijemo najpre kako mislimo jezik na kojem mislimo, ali i da odemo korak dalje - da saznamo kako srpski jezik misle oni koji o njemu uče, služe se njime i o njemu misle. Imajući u vidu da se bavimo ispitivanjem vladajućih koncepcija o srpskom jeziku (u multinacionalnoj studentskoj zajednici), najpre ćemo se osvrnuti na značaj koncepcija za učenje.

\subsection{Koncepcije i učenje}

U studiji „Didaktika i metakognicija” (Gojkov, 2009) ukazuje se na to da svaka osoba ima određena uverenja o svetu koji je okružuje, i ona pokreće operativne procedure. Ako nema uverenja o pitanju/pojmu pred kojim je, onda dolazi do manipulacije drugim idejama o tom pitanju/pojmu što dovodi do snažne interferencije. Ovaj sistem misli - koncepcija - ima zadatak da usmerava način na koji onaj koji uči dekodira informaciju i formuliše svoje nove ideje. Usvajanje novih znanja integracija je novog znanja u postojeću strukturu misli; kroz sopstveno znanje dešifruju se novi podaci i upoređuju (ibidem, 168). U procesu učenja, po nekim shvatanjima (alosterični model), ne možemo ignorisati činjenicu da postoje prethodne koncepcije koje su prepreka za nove nivoe organizacije ideja (ibidem, 174); usvajanje znanja odvija se kao proširivanje prethodnog znanja i u suprotnosti sa njim. Kada se razumeva nova ideja, polazi se od postojećeg znanja, „uz korišćenje jednostavnih alatki: sopstvenih koncepcija”, koje su ,jedine alatke koje [učeniku/studentu] stoje na raspolaganju u dešifrovanju realnosti" (ibidem, 70). Do učenja dolazi tek kada se učenici/studenti odalje od svojih prvobitnih koncepata, kada usvoje novi koncept, što podrazumeva da je i njihova prethodna mentalna struktura duboko transformisana (jer najčešće prethodno znanje

\footnotetext{
${ }^{3}$ Zakonski i podzakonski akti dostupni su na sajtu Ministarstva prosvete Republike Srbije (www.mp.gov.rs/propisi).
} 
predstavlja prepreku za integraciju novog znanja). Oni koji uče treba da odluče da promene svoje koncepcije, a zadatak je nastavnika da stalno pred njih postavlja izazove, dok postojeće koncepcije ne počnu da vode do odgovora. Da bi taj proces bio uspešniji, na nastavniku je i da otkrije vladajuće koncepcije kod mladih sa kojima radi. Pogotovo je važno otkrivanje ometajućih koncepata - onih koji vode u pogrešno postupanje (npr. do pravopisne greške, nemarnog odnosa prema određenom nastavnom gradivu i sl.) - čemu sledi metodičko osmišljavanje časa koji će, odgovarajućim metodičkim postupcima, uvesti delatne metafore i stvoriti podsticajno okruženje i kontekst da se stare koncepcije zamene novim.

Metodičke impute/obrazovno okruženje učenik/student treba da oseti kao izazove „kako bi bio spreman da integriše novostečenu informaciju i proizvede nova značenja koja su kompatibilna sa organizacijom njihove mentalne strukture (koju već poseduju)" (ibidem, 72). Pojava novih koncepcija zavisi, dakle, od unutrašnjih uslova, kao i od spoljnih uslova. Obrazovno okruženje treba da potpomogne sumnju u prethodne koncepte i da se problem sagleda iz drugog ugla, da budu prilagođeni konceptualnom okviru mladih, a učenici/studenti valja da su podstaknuti da ,misle o svojim konceptualnim praksama” (ibidem, 73). S namerom da otkrijemo vladajuće koncepte/stavove/uverenja/koncepcije kod mladih, možemo se, između ostalog, opredeliti da primenjujemo teorijsko-metodološki aparat kognitivne lingvistike.

\subsection{Osvrt na kognitivni pristup}

Kognitivna lingvistika podrazumeva ,istraživanje značenjskog tkiva, satkanog nit po nit od telesnog iskustva i izvezenog metaforom i metonimijom" (Janda, 2010, prema: Klikovac, 2018: 7). Popularizovana je od sedamdesetih i osamdesetih godina prošloga veka (najpre u svetu, pa kasnije i kod nas), a danas se sve intenzivnije koristi i za metodička promišljanja nastavnih postupaka. U okviru kognitivne lingvistike metafora se shvata kao mehanizam mišljenja i naziva pojmovnom metaforom (isp. Klikovac, 2004; Lakoff \& Johnson, 1980, 2003; Lakoff, 1993). Pojmovna metafora je mehanizam na osnovu kojeg jedan pojam razumemo pomoću nekog drugog, iskustveno bližeg pojma, pri čemu su iskustveno bliži pojmovi veoma često konkretni, a iskustveno dalji pojmovi apstraktni (Radić Bojanić, 2012: 266). Najvažnije je razumevanje jednog pojma kao drugog, pri čemu težimo da apstrakcije konkretizujemo. Rečeno je i u skladu sa mišljenjem Dž. Brunera, koji tvrdi da se: „bilo koja ideja ili problem ili količina znanja može razumeti u prepoznatljivom obliku" (Bruner, 1990: 290, prema: Gojkov, 1995: 129). Primera radi, R. Dragićević u udžbeniku za peti razred osnovne škole - da bi učenicima ovoga uzrasta približila apstraktne jezičke sadržaje - uvodi metaforu JEZIK JE NAŠA KUĆA. Domen koji „pozajmljuje” svoju strukturu - bazični, izvorni (sourse domain) je (NAŠA) KUĆA, a onaj koji se na osnovu njega razumeva (ciljni - target domain), koji se želi objasniti je JEZIK. Znanja o jednom domenu preslikavaju se na znanja o drugom, apstraktnom domenu; o ciljnom pojmu razmišlja se uz pomoć znanja koja imamo o izvornom pojmu (o jeziku se govori kao o kući). U prilog rečenom su, na primer, i rezultati ankete Metafore o nastavi, učenju, učenicima i nastavnicima maternjeg jezika (sprovedene 2007/2008. godine među studentima treće godine grupe za srpski jezik i književnost Filološkog fakulteta u Beogradu, v. Veljković Stanković, 2009: 103-117), koji su pokazali da u razumevanju apstraktnih sadržaja (v. naslov ankete) u većini slučajeva dominiraju npr. metafore puta (UČENJE JE PUTOVANJE; NASTAVNIK JE VODIČ/PUTOVOĐA; UČENIK JE PUTNIK), rasta, negovanja (UČENJE JE /DUHOVNI/ RAST; NASTAVNIK JE NEGOVATEL/BAŠTOVAN; UČENIK JE CVET/BILKA) i umetničkog stvaralaštva (NASTAVA/ČAS JE UMETNIČKO DELO; NASTAVNIK JE UMETNIK/STVARALAC) (ibidem, 103) itd. 
Rečju, pojmovna metafora povezana je s načinom na koji razumemo stvarnost - prilikom razumevanja nepoznatih pojmova i pojmovnih domena služimo se onim što nam je poznato, te apstraktne poimamo preko konkretnih, bliskih i poznatih pojava i realija (up. princip postupnosti i sistematičnosti, pravila postupnosti, Nikolić ${ }^{4} 2006$ : 109-116, 110). Metafore postaju matrica ponašanja i mišljenja, metaforama obznanjujemo svoja uverenja, one su „spoljni izraz duhovne potrebe da jedne činjenice preslikava na druge, bar prividno shvatljive ili izrazitije, u cilju da se učine razumljivi, izrazitiji ili ulepšanim" (Petrović, 1942/1967: 22, prema: Antović, 2007: 196, grafičko isticanje I. Đ.).

\subsubsection{Pojmovna metafora kao kognitivna alatka}

Imajući u vidu sve prethodno rečeno, ne iznenađuje da su mnoga istraživanja vezana za ispitivanje koncepcija učesnika u vaspitno-obrazovnom procesu. Nabrojaćemo samo neka od onih u kojim su pojmovne metafore korišćene kao alatke za bolje razumevanje koncepcija u vaspitno-obrazovnom procesu, i to o mnogim vaspitno-obrazovnim pojmovima i pojavama, ali i za metodička promišljanja nastavnih postupaka. Tako su, na primer, teorijsko-metodološkom aparaturom kognitivne lingvistike, razmatrane vladajuće koncepcije (stavovi/uverenja) u vezi sa: (a) obrazovanjem kao opštim pojmom (Cook-Sather, 2003: 946-977); (b) učenjem uopšte (Brendt, 2008: 73-102); (c) učenjem maternjeg jezika (Veljković Stanković, 2009: 103-117); (č) učenjem stranoga jezika (Caballero, 2006: 201-209); (ć) unapređivanjem nastave gramatike, ortografije, leksike... (Farjami, 2012: 19-41; Klikovac, 2004, 2018; Veljković Stanković, 2008: 497-510, 2013: 85-113, 2018a: 259-274 / Đorđev, 2014: 130-143; Veljković Stanković i Đorđev, 2018a: 41-53 / Veljković Stanković, 2018b); (d) unapređivanjem pismenosti uopšte (Veljković Stanković i Đorđev, 2018b: 7-22; Đorđev, 2019: 127-142); (dž) korišćenjem udžbenika (Kesen, 2010); (đ) nastavom, učenicima i nastavnicima maternjeg jezika (Veljković Stanković, 2009: 103-117), kao i oni [stavovi/uverenja] koji se tiču (e) pojmova uspešan učenik, uspešan nastavnik, uspešna nastava (Nagamine, 2012: 141-171), (f) dramski metod (Đorđev i Kelemen Milojević, 2017: 275-284), (g) komunikacija u multinacionalnoj studentskoj zajednici (Đorđev i Raić, 2018: 55-69) itd.

Stavovi prema jeziku „odražavaju govornikov subjektivni stav prema jezičkim elementima, stav pojedinca ili određene grupe pojedinaca prema nekom jeziku, jezičkom varijetetu, jezičkim pojavama i elementima ili upotrebi jezika, te njihovo izražavanje mišljenja o svemu ovome" (Gréczi-Zsoldos, 2011, prema: Kovač Rac i Halupka Rešetar, 2017: 143), a pozitivan stav prema nekom jeziku je jedan od osnovnih faktora koji doprinose uspešnom učenju tog jezika, jer se usled njega javlja spremnost i motivacija za učenje jezika (Brown, 2000; Petterei, 2015: 47, prema: Kovač Rac i Halupka Rešetar, 2017: 141-142). Imajući u vidu da je „nastava jezika onakva kakva je njena metaforička konceptualizacija” (Veljković Stanković, 2009: 103), sproveli smo istraživanje metaforičkih konceptualizacija o srpskom jeziku na studentskoj populaciji. Metodološki okvir istraživanja, kao i rezultate i diskusiju donosimo u nastavku.

\section{Metodološki okvir}

Predmet istraživanja ovoga rada jesu metaforičke konceptualizacije studenata o srpskom jeziku, kao maternjem ali i kao nematernjem jeziku. Osnovni problem istraživanja može se formulisati u vidu sledećeg pitanja: Mogu li se otkrivanjem i detaljnijim proučavanjem vladajućih koncepata studenata o srpskom jeziku mapirati polja u kojima treba unaprediti (visokoškolsku) nastavu srpskog jezika? Cilj istraživanja jeste da se primenom teorijsko-metodološkog aparata 
kognitivne lingvistike otkrije kako studenti kojima je maternji jezik srpski/rumunski/romski doživljavaju (konceptualizuju) većinski, jezik sredine - srpski jezik.

Zadaci istraživanja su: (a) otkriti, kroz analizu pojmovnih metafora o srpskom jeziku, kako studenti čiji je maternji jezik srpski/rumunski/romski poimaju srpski jezik; (b) uporediti stavove studenata čiji je maternji jezik srpski sa stavovima studenata kojima je srpski nematernji jezik, osvetljujući, kada za tim ima potrebe, i razlike u koncepcijama među studentima različitih nivoa studija (osnovne : master strukovne studije); (c) osvetliti vladajuće koncepte kada je reč negovanju srpskoga jezika, posebno ortografije, kao i unapređivanja nastave ovoga predmeta na visokoškolskim ustanovama.

Primarna hipoteza od kojih smo u analizi pošli nakon određivanja ciljeva rada je: Otkrivanje i detaljnije proučavanje vladajućih koncepata studenata o srpskom jeziku identifikuje polja u kojima treba unaprediti nastavu ovoga jezika. Operativne (radne) hipoteze su brojne:

H1: Srpski jezik iz perspektive studenata (svih koji su učestvovali u istraživanju) doživljava se kao kompleksan pojam.

H1(a): Studenti kojima je srpski jezik maternji jezik imaju izrazito afirmativan stav prema svom jeziku.

H1(b): Studenti kojima je srpski nematernji jezik (Rumuni, Romi) vide ovaj jezik kao sredstvo komunikacije, odnosno ističu komunikativnu ulogu jezika sredine.

H2: Aktivnostima eksplicitno usmerenim na usavršavanje/negovanje srpskoga jezika studenti posvećuju dnevno od 15 minuta do 45 minuta (najduže jedan školski čas).

$\mathrm{H} 2(\mathrm{a})$ : Studenti kojima je srpski maternji jezik aktivnostima usmerenim na usavršavanje/negovanje srpskoga jezika posvećuju dnevno do 15 minuta.

$\mathrm{H} 2(\mathrm{~b})$ : Studenti kojima je srpski jezik nematernji, aktivnostima usmerenim na usavršavanje/negovanje srpskoga jezika posvećuju sat-dva dnevno.

H3: Aktivnostima eksplicitno usmerenim na učenje/usavršavanje nekog od stranih jezika (engleskog, nemačkog, ruskog, francuskog, italijanskog i dr.) studenti posvećuju sat-dva dnevno.

H3(a): Studenti kojima je srpski maternji jezik aktivnostima eksplicitno usmerenim na učenje/usavršavanje nekog od stranih jezika posvećuju sat-dva dnevno.

$\mathrm{H}_{3}$ (b): Studenti kojima je srpski jezik nematernji, aktivnostima eksplicitno usmerenim na učenje/usavršavanje nekog od stranih jezika posvećuju sat-dva dnevno.

H4: Da bi unapredili poznavanje srpskog jezika, studenti najčešće koriste internet i druge elektronske izvore.

H4(a): Studenti kojima je srpski jezik maternji jezik za unapređivanje svoga jezika najčešće koriste internet i druge elektronske izvore.

H4(b): Studenti kojima je srpski jezik nematernji jezik pohađaju van nastave specijalizovane kurseve iz srpskog jezika.

H5: Studenti imaju pomirljiv (egalistički) stav kada je reč o poštovanju pravopisnih pravila u srpskom jeziku.

H5(a): Studenti kojima je maternji jezik srpski jezik ističu važnost negovanja kulture govora i upotrebe lepih reči.

H5(b): Studenti kojima je srpski nematernji jezik ističu problem (mnoštva) pravopisnih grešaka u pismenom izražavanju.

H6: Kada je reč o mogućnostima unapređivanja visokoškolske nastave srpskoga jezika, studenti smatraju da je presudna uloga kvantiteta, odnosno da nastavi srpskog jezika treba posvetiti više časova predavanja, vežbi, ali i seminara, kao i dopunskog rada. 
H6(a): Studenti kojima je srpski jezik maternji jezik najčešće unapređivanje nastave srpskog jezika vide u povećanom broju časova nastave, seminara i radionica.

H6(b): Studenti kojima je srpski jezik nematernji jezik najčešće unapređivanje nastave srpskog jezika vide u intenzivnijoj upotrebi informaciono-komunikacionih tehnologija [u daljem tekstu: IKT].

Priroda i svrha istraživanja uslovile su opredeljenje za namerni uzorak - istraživanjem je obuhvaćeno ukupno 100 studenata (v. Tabelu 1): 50 studenata prvog nivoa studija (osnovne strukovne studije) i 50 studenata koji pohađaju studije drugog nivoa (master strukovne studije) Visoke škole strukovnih studija za vaspitače „Mihailo Palov”, Vršac. Od ukupnog uzorka, 10 je studenata na romskom nastavnom jeziku i 10 studenata kojima je maternji jezik rumunski jezik (s obzirom na ukupan broj studenata koji na ovoj visokoj školi studiraju na romskom i rumunskom jeziku, ovo je bio broj do kojeg se u trenutku istraživanja moglo doći).

Tabela 1. Uzorak istraživanja

\begin{tabular}{|c|c|c|c|c|c|}
\hline Osnovni podaci & OSS & OSSRUM & OSSROM & MSS & Ukupno \\
\hline Broj ispitanika & 30 & 10 & 10 & 50 & 100 \\
\hline Pol & 27 ž; 3 m & 9 ž; $1 \mathrm{~m}$ & 8 ž; $2 \mathrm{~m}$ & 48 ž; $2 \mathrm{~m}$ & 92 ž, $8 \mathrm{~m}$ \\
\hline $\begin{array}{l}\text { Datum } \\
\text { anketiranja }\end{array}$ & $\begin{array}{l}14.10 . \\
2019 .\end{array}$ & 21. 10. 2019. & $\begin{array}{l}9.10 .2019 . \\
12.11 .2019 .\end{array}$ & $\begin{array}{c}\text { 19. 10. } 2019 . \\
\text { 18. 1. } 2020 .\end{array}$ & $\begin{array}{c}\text { od 9.10.2019 do } \\
18.1 .2020 .\end{array}$ \\
\hline
\end{tabular}

Legenda: OSS - Osnovne strukovne studije na srpskom jeziku; OSSRUM - osnovne strukovne studije na rumunskom jeziku; OSSROM - osnovne strukovne studije na romskom jeziku; MSS - master strukovne studije; m - muški pol; ž - ženski pol.

Svi ispitanici, i studenti kojima je maternji jezik srpski i oni kojima je maternji jezik rumunski ili romski, pohađaju časove predavanja i vežbi iz srpskoga jezika u trajanju od jednog semestra $(3+1)$ na prvoj godini osnovnih strukovnih studija ${ }^{4}$. Ciljevi ovoga kursa su: dobro poznavanje gramatičkog sistema srpskog jezika na svim jezičkim nivoima, na teorijskoj i praktičnoj ravni; kompetentna ovladanost pravopisom i osposobljenost za samostalne leksikološke, sintaksičke i ortografske analize tekstova. Po uspešnom završetku kursa, od studenata se očekuje da: opisuju poreklo, razvoj i raslojavanja srpskog standardnog (književnog) jezika, kao i gramatičko-leksikografske instrumente za normiranje jezika i pravopisa; razlikuju sve jezičke nivoe i norme srpskog književnog jezika; primenjuju teorijska znanja za samostalnu leksikološku, sintaksičku i ortografsku analizu tekstova; upotrebljavaju standardni srpski jezik efikasno u vaspitnoj grupi; vrednuju važnost stalnog usavršavanja iz jezika i pravopisa.

Predavanja su zajednička za sve studente, dok su grupe za vežbe formirane tako da posebnu grupu čine studenti kojima srpski nije maternji jezik, što omogućava prilagođavanje rada nivou znanja, umenja i postignuća studenata iz ovoga jezika, kao i kombinovanje metodike nastave maternjeg i stranog jezika. Većina studenata o kojima je ovde reč nastavu srpskog jezika pratila je u osnovnoj i u srednjoj školi i uspešno se srpskim jezikom služe u svakodnevnoj komunikaciji. Studenti kojima je srpski jezik nematernji nakon pohađanja kursa imaju pravo da polažu ispit, ali im ocena ne ulazi u opšti prosek studiranja (podatak o položenom ispitu evidentira se u Dodatku diplome).

U periodu od oktobra 2019. do kraja januara 2020. godine ispitanici (8 studenata i 92 studentkinje), popunilo je anonimni anketni upitnik, sačinjen od pet pitanja mešovitog (otvorenog i zatvorenog) tipa. Upitnik je koncipiran tako da otkrije: (a) izvorne domene preko

\footnotetext{
${ }^{4} \mathrm{~V}$. Informator za studente. Knjiga predmeta.
} 
kojih studenti razumevaju srpski jezik, (b/c) procenu vlastitog angažovanja i načina usavršavanja/negovanja srpskoga jezika, kao i učenja/usavršavanja stranog jezika, (č) stav učenika prema poznavanju jezičkih pravila i pravopisa maternjeg jezika, (ć) osvetljavanju vladajućih koncepata kada je reč o unapređivanju nastave ovoga predmeta na visokoškolskim ustanovama.

Priprema i tok istraživanja. - Odlučeno je da se posebno osmišljeni anketni upitnici prikupljaju tokom zimskom semestra školske 2019/2020. godine i to tako da se ne remeti nastavni proces. Pre ankete studentima su predočeni ciljevi istraživanja, a takođe je objašnjena razlika između pojmovne i poetske metafore. Prikupljeni podaci obrađeni su analitičkom, deskriptivnom i kognitivnom metodom, a posmatrani su sumarno i komparativno, te propraćeni kratkim diskusijama, s obzirom na problematiku pokrenutu određenim pitanjima. Svako od 5 anketnih pitanja navedeno je (u izvornom obliku) u zaglavlju posebnih tabela (isp. niže tabele 2-7).

\section{Rezultati i diskusija}

3.1. Na prvo pitanje ankete koje tematizuje poimanje srpskoga jezika od strane anketiranih studenata (svih nivoa studija), dobijeno je ukupno 90 odgovora, dok je 10 upitnika bilo bez odgovora na ovo pitanje (v. Tabelu 2).

Rezultati ankete pokazali su da studenti srpski jezik najčešće (15\% odgovora) poimaju preko sledećih pojmovnih metafora: SRPSKI JEZIK JE PROSTOR, NEDOVOLJNO ISTRAŽEN I NEPOZNAT PROSTOR (up. [SRPSKI JEZIK JE]: LAVIRINT/OKEAN/TUNEL/GUSTA ŠUMA/OGROMNO MORE). Izbor ovog izvornog domena ukazuje na to da su studenti svesni vlastite nesigurnosti prilikom primene znanja iz srpskog jezika, kao i da postoji određena odbojnost i zazor pred pravilima koje uspešno usmeno i pismeno izražavanje na ovom jeziku podrazumeva. Odmah za tim po zastupljenosti (14\%) jesu metafore koje otkrivaju stav studenata da se srpski jezik poima kao VREDAN I REDAK ENTITET: [SRPSKI JEZIK JE]: BLAGO/ZLATO/ZLATO MATERINO/BOGATSTVO SRPSKOG NARODA/BISER/ĆUP SA ZLATOM. Najzastupljeniji izvorni domen u ovom slučaju je zlato, veoma retka ali vredna pojava. Dalje su rezultati ankete pokazali da u 13\% odgovora dominira metafora dugotrajnog puta (SRPSKI JEZIK DOŽIVLJAVAM KAO: PUTOVANJE/PUTOVANJE KROZ KOJE UČIMO/PUT BEZ KRAJA /AVANTURISTIČKO PUTOVANJE/PUTOVANJE KOJE TRAJE DOK SMO ŽIVI). Ova metafora ne iznenađuje budući da se učenje jezika često poima kao putovanje (v. Veljković Stanković, 2009: 103-117), tj. kao manje ili više naporno kretanje prema određenom cilju. Prema Lejkofu NAPREDAK U UČENJU (MATERNJEG JEZIKA) JESTE PREĐENI DEO PUTA, A ZNANJE JE CILJ PUTOVANJA (Lakoff et al., ${ }^{2} 1991: 37$ ). Metaforu puta nalazimo i u učenju stranog jezika (up. Caballero, 2006: 203-207; Martinez et al., 2001: 970). Od ostalih metaforičkih konceptualizacija koje su studenti izgradili izdvajamo poimanje srpskog jezika preko izvornog domena čvrste KONSTRUKCIJE/GRAĐEVINE (7\%), (UP. SRPSKI JEZIK JE NAŠA KUĆA, Dragićević, 2006: 127-128), dok je posebno zanimljiva, iako zastupljena u svega 5\% odgovora, konceptualizacija srpskog jezika kao AUDITIVNOG/ZVUČNOG ENTITETA ([SRPSKI JEZIK JE]: MELEM ZA UŠI/POTOK KOJI ŽUBORI/MELODIJA ZA DUŠU/ INSTRUMENT KOJI SE NAJLEPŠE SVIRA). Ove metafore otkrivaju osetljivost govornika na melodičnost i ,,milozvučnost” jezika.

Uočili smo da su veoma retke (5\%) metafore koje pokazuju da studenti srpski jezik doživljavaju kao neophodan i važan element komunikacije (SRPSKI JEZIK JE ALAT ZA RAZGOVOR/DIJALOŠKO ORUĐE/SREDSTVO PRENOŠENJA MISLI I OSEĆANJA), odnosno u odgovorima ispitanika zapostavljena je komunikativna uloga jezika. Ostali, manje zastupljeni koncepti, prikazani su u Tabeli 2. Zaključujemo da na ukupnom uzorku dominira osam različitih koncepata o srpskom jeziku, 
čime je potvrđena hipoteza H1: Srpski jezik iz perspektive studenata doživljava se kao kompleksan pojam.

Tabela 2. Konceptualizacija srpskoga jezika iz perspektive studenata(ukupni uzorak)

\begin{tabular}{|c|c|c|}
\hline \multicolumn{3}{|c|}{$\begin{array}{l}\text { Pitanje br. } 1 \\
\text { Kako doživljavate/poimate srpski jezik? }\end{array}$} \\
\hline $\begin{array}{l}\text { CILJNI DOMEN } \\
\text { [Srpski jezik je]: }\end{array}$ & IZVORNI DOMENI & $\begin{array}{l}\text { Procentualna } \\
\text { zastupljenost }\end{array}$ \\
\hline $\begin{array}{l}\text { Nedovoljno istražen i nepoznat } \\
\text { prostor }\end{array}$ & LAVIRINT/OKEAN/TUNEL/GUSTA ŠUMA/OGROMNO MORE & $15 \%$ \\
\hline Vredan/važan entitet & $\begin{array}{l}\text { BLAGO/ZLATO/ZLATO MATERINO/BOGATSTVO SRPSKOG } \\
\text { NARODA/BISER/ĆUP SA ZLATOM }\end{array}$ & $14 \%$ \\
\hline Put/putovanje & $\begin{array}{l}\text { PUTOVANJE/PUTOVANJE KROZ KOJE UČIMO/PUT BEZ } \\
\text { KRAJA / AVANTURISTIČKO PUTOVANJE/ PUTOVANJE KOJE } \\
\text { TRAJE DOK SMO ŽIVI }\end{array}$ & $13 \%$ \\
\hline (Čvrsta) građevina/konstrukcija & TEMEL/STUB/OSLONAC/OSNOVA/TVRĐAVA/DOM & $7 \%$ \\
\hline $\begin{array}{l}\text { Auditivni/zvučni entitet /element } \\
\text { (up. melodičnost) }\end{array}$ & $\begin{array}{l}\text { MELEM ZA UŠI/POTOK KOJI ŽUBORI/ MELODIJA ZA } \\
\text { DUŠU/INSTRUMENT KOJI SE NAJLEPŠE SVIRA }\end{array}$ & $5 \%$ \\
\hline $\begin{array}{l}\text { Sredstvo komunikacije } \\
\text { (up. komunikativna uloga jezika) }\end{array}$ & $\begin{array}{l}\text { JEZIK KOMUNIKACIJE/ALAT ZA RAZGOVOR/DIJALOŠKO } \\
\text { ORUĐE/ SREDSTVO PRENOŠENJA MISLI I OSEĆANJA }\end{array}$ & $5 \%$ \\
\hline Predmet & ENCIKLOPEDIJA/KNJIGA/ZANIMLIVO ŠTIVO - PUTOPIS & $5 \%$ \\
\hline Živo biće & BORAC/ MAJKA/TO SAM JA (DEO MENE) & $4 \%$ \\
\hline Razno & $\begin{array}{l}\text { ZABAVA/KULTURA/KREATIVNOST/ } \\
\text { OBRAZOVANOST/MOZAIK }\end{array}$ & $22 \%$ \\
\hline $\mathrm{BO}$ & 1 & $10 \%$ \\
\hline Ukupno & 8 dominantnih koncepata & $100 \%$ \\
\hline
\end{tabular}

Legenda: $\mathrm{BO}$ - bez odgovora.

Razmatranje konceptualizacije srpskog jezika studenata kojima je on maternji jezik (v. Tabelu 3) pokazuje da na osnovnim studijama dominira viđenje srpskog jezika kao nedovoljno istraženog i nepoznatog prostora (9 odgovora), dok se na drugom nivou studija (među starijim ispitanicima) izdvaja doživljaj srpskog, odnosno maternjeg jezika kao izuzetno vrednog i važnog entiteta. Stoga ne možemo reći da je H1(a): Studenti kojima je srpski jezik maternji jezik imaju izrazito afirmativan stav prema svom jeziku - u celosti potvrđena. Kada u fokusu imamo govornike rumunskog i romskog jezika, srpski jezik kao nematernji jezik se vidi kao važan entitet i kao putovanje (up. UČENJE JE PUTOVANJE), v. Tabelu 3. lako smo očekivali da ovi studenti izdvoje komunikativnu ulogu jezika kao većinskog jezika sredine, takvi odgovori su izostali (svega je jedan student istakao srpski jezik kao sredstvo komunikacije u multikulturalnoj vojvođanskoj sredini), odnosno konstatujemo da $\mathrm{H}_{1}(\mathrm{~b})$ : Studenti kojima je srpski nematernji jezik (Rumuni, Romi) vide ovaj jezik kao sredstvo komunikacije, odnosno ističu komunikativnu ulogu jezika sredine - nije potvrđena.

Tabela 3. Konceptualizacija srpskoga jezika (prema nivoima studija i nastavnom jeziku)

\begin{tabular}{|l|c|c|c|c|c|}
\hline $\begin{array}{l}\text { Pitanje br. 1 } \\
\text { Kako doživljavate/poimate }\end{array}$ & $\begin{array}{c}\text { OSS } \\
\text { srpski jezik? }\end{array}$ & $\begin{array}{c}\text { OSSRUM } \\
\text { [Srpski jezik je]: }\end{array}$ & $\begin{array}{c}\text { OSSROM } \\
10\end{array}$ & MSS & Ukupno \\
100 & & \\
\hline $\begin{array}{l}\text { Nedovoljno istražen i } \\
\text { nepoznat prostor }\end{array}$ & 9 & 0 & 1 & 5 & $15 \%$ \\
\hline Vredan/važan entitet & 2 & 2 & 1 & 9 & $14 \%$ \\
\hline Put/putovanje & 3 & 0 & 3 & 7 & $13 \%$ \\
\hline
\end{tabular}




\begin{tabular}{|l|c|c|c|c|c|}
\hline $\begin{array}{l}\text { (Čvrsta)građevina/ } \\
\text { konstrukcija }\end{array}$ & 1 & 1 & 2 & 3 & $7 \%$ \\
\hline $\begin{array}{l}\text { Auditivni/zvučni entitet } \\
\text { lelement (up. melodičnost) }\end{array}$ & 1 & 1 & 0 & 3 & $5 \%$ \\
\hline $\begin{array}{l}\text { Sredstvo komunikacije } \\
\text { (up. komunikativna uloga) }\end{array}$ & 0 & 1 & 0 & 4 & $5 \%$ \\
\hline Predmet & 3 & 0 & 0 & 2 & $5 \%$ \\
\hline Živo biće & 2 & 0 & 0 & 2 & $4 \%$ \\
\hline Razno & 9 & 1 & 2 & 10 & $22 \%$ \\
\hline BO & 0 & 4 & 1 & 5 & $10 \%$ \\
\hline Ukupno odgovora & $100 \%$ & $60 \%$ & $90 \%$ & $90 \%$ & $90 \%$ \\
\hline Ukupno \% & $(30)$ & $(6)$ & $(9)$ & $(45)$ & $(90)$ \\
\hline
\end{tabular}

3. 2. Pitanjem br. 2 želeli smo da utvrdimo koliko vremena studenti posvećuju usavršavanju i negovanju, s jedne strane, srpskoga jezika (A), a s druge strane stranoga jezika (B). Na ukupnom uzorku (v. Tabela 4) uočljivo je da je najviše studenata (31\%) odabralo odgovor pod c), čime je potvrđena H2: Aktivnostima eksplicitno usmerenim na usavršavanje/negovanje srpskoga jezika studenti posvećuju dnevno od 15 minuta do 45 minuta (najduže jedan školski čas).

Dalje smo želeli da ispitamo koliko vremena prema sopstvenoj proceni usavršavanju i negovanju jezika posvećuju (a) studenti kojima je srpski jezik maternji i (b) studenti kojima je srpski nematernji jezik. lako smo pretpostavili, imajući u vidu dinamiku svakodnevice, te greške u govoru i pisanju sa kojima se svakodnevno srećemo, da studenti kojima je srpski maternji jezik aktivnostima usmerenim na usavršavanje/negovanje jezika posvećuju dnevno do 15 minuta ( $\left.\mathrm{H}_{2}(\mathrm{a})\right)$, studenti su odgovorili drugačije, procenjujući da tokom osnovnih studija tome posvećuju najduže jedan školski čas, dok se tokom master studija to vreme produžava na sat-dva dnevno. Konstatujemo da $\mathrm{H} 2$ (a): Studenti kojima je srpski maternji jezik aktivnostima usmerenim na usavršavanje/negovanje srpskoga jezika posvećuju dnevno do 15 minuta nije potvrđena. Moguće je da je delimično na ovakav rezultat uticala i svest studenata, pogotovo drugog nivoa studija, o tome koji su odgovori od njih očekivani.

Studenti kojima je srpski jezik nematernji, aktivnostima usmerenim na usavršavanje/negovanje srpskoga jezika posvećuju do 15 minuta (rumunski) ili od 15 minuta do 45 minuta dnevno (romski), čime nije potvrđena $\mathrm{H}_{2}(\mathrm{~b})$ : Studenti kojima je srpski jezik nematernji, aktivnostima usmerenim na usavršavanje/negovanje srpskoga jezika posvećuju sat-dva dnevno, a kojom smo pretpostavili da ovi studenti više vremena provode učeći jezik sredine.

Kada u fokusu imamo učenje nekog od stranih jezika (engleskog, nemačkog, ruskog, francuskog, italijanskog i dr.) (B), studenti su, gledajući ukupan uzorak, najčešće (38\%) isto procenjivali kao i kada je u pitanju usavršavanje/negovanje srpskog jezika: aktivnostima eksplicitno usmerenim na učenje/usavršavanje nekog od stranih jezika (engleskog, nemačkog, ruskog, francuskog, italijanskog i dr.) studenti posvećuju dnevno od 15 minuta do 45 minuta (najduže jedan školski čas). Svega je $11 \%$ studenata zaokružilo odgovor pod č) kojim se procenjuje da se učenju stranog jezika posvećuje sat-dva dnevno, dok više sati svakoga dana strani jezik uči svega 3\% studenata.

Ako posebno pogledamo dominantne odgovore studenata kojima je srpski jezik maternji (oba studijska nivoa) i odgovore studenata kojima je srpski nematernji (v. Tabela 4), vidimo da uglavnom dominiraju odgovori pod c) [aktivnostima usmerenim na usavršavanje/učenje 
stranog jezika posvećujem] od 15 do 45 minuta (najduže jedan školski čas). Zaključujemo da su $\mathrm{H}_{3}, \mathrm{H}_{3}(\mathrm{a})$ i H3(b): Aktivnostima eksplicitno usmerenim na učenje/usavršavanje nekog od stranih jezika (engleskog, nemačkog, ruskog, francuskog, italijanskog i dr.) studenti / studenti kojima je srpski maternji jezik / studenti kojima je srpski jezik nematernji, posvećuju sat-dva dnevno utopijske (nepotvrđene) hipoteze i izgleda više su proizvod želje nastavnika/istraživača no slika realnog stanja.

Tabela 4. Trajanje dnevnih aktivnosti usmerenih na usavršavanje/negovanje srpskoga i usavršavanje/učenje stranoga jezika iz perspektive studenata

\begin{tabular}{|c|c|c|c|c|c|}
\hline $\begin{array}{l}\text { Pitanje br. } 2 \\
\text { Prema Vašoj slobodnoj proceni, } \\
\text { koliko vremena tokom dana } \\
\text { posvetite aktivnostima } \\
\text { usmerenim na } \\
\text { usavršavanje/negovanje/ } \\
\text { učenje: }\end{array}$ & $\begin{array}{c}\text { OSS } \\
30\end{array}$ & $\begin{array}{c}\text { OSSRUM } \\
10\end{array}$ & $\begin{array}{c}\text { OSSROM } \\
10\end{array}$ & $\begin{array}{c}\text { MSS } \\
50\end{array}$ & $\begin{array}{c}\text { Ukupno } \\
100\end{array}$ \\
\hline A. srpskoga jezika & $\begin{array}{l}\text { a) } 4 \% \\
\text { b) } 5 \% \\
\text { c) } 13 \% \\
\text { c) } 4 \% \\
\text { ć) } 2 \% \\
\text { d) } 2 \%\end{array}$ & $\begin{array}{l}\text { a) } 0 \% \\
\text { b) } 7 \% \\
\text { c) } 0 \% \\
\text { c) } 3 \% \\
\text { ć) } 0 \% \\
\text { d) } 0 \%\end{array}$ & $\begin{array}{l}\text { a) } 0 \% \\
\text { b) } 0 \% \\
\text { c) } 8 \% \\
\text { c) } 0 \% \\
\text { ć) } 2 \% \\
\text { d) } 0 \%\end{array}$ & $\begin{array}{l}\text { a) } 2 \% \\
\text { b) } 9 \% \\
\text { c) } 10 \% \\
\text { c) } 18 \% \\
\text { c) } 7 \% \\
\text { d) } 4 \%\end{array}$ & $\begin{array}{l}\text { a) } 6 \% \\
\text { b) } 21 \% \\
\text { c) } 31 \% \\
\text { č) } 25 \% \\
\text { c) } 11 \% \\
\text { d) } 6 \% \\
100 \%\end{array}$ \\
\hline $\begin{array}{l}\text { B. stranoga (engleskog, } \\
\text { nemačkog, ruskog, francuskog, } \\
\text { italijanskog i dr.) jezika }\end{array}$ & $\begin{array}{l}\text { a) } 5 \% \\
\text { b) } 4 \% \\
\text { c) } 17 \% \\
\text { č) } 2 \% \\
\text { ć) } 1 \% \\
\text { d) } 1 \%\end{array}$ & $\begin{array}{l}\text { a) } 0 \% \\
\text { b) } 1 \% \\
\text { c) } 7 \% \\
\text { c) } 1 \% \\
\text { c) } 1 \% \\
\text { d) } 0 \%\end{array}$ & $\begin{array}{l}\text { a) } 0 \% \\
\text { b) } 3 \% \\
\text { c) } 5 \% \\
\text { c) } 2 \% \\
\text { ć) } 0 \% \\
\text { d) } 0 \%\end{array}$ & $\begin{array}{l}\text { a) } 8 \% \\
\text { b) } 18 \% \\
\text { c) } 9 \% \\
\text { c) } 6 \% \\
\text { c) } 1 \% \\
\text { d) } 8 \%\end{array}$ & $\begin{array}{l}\text { a) } 13 \% \\
\text { b) } 26 \% \\
\text { c) } 38 \% \\
\text { č) } 11 \% \\
\text { c) } 3 \% \\
\text { d) } 9 \% \\
100 \%\end{array}$ \\
\hline
\end{tabular}

Legenda:

a) nemam vremena da se bavim aktivnostima usmerenim na negovanje srpskoga/stranoga jezika; b) do 15 minuta svakoga dana; c) od 15 do 45 minuta (najduže jedan školski čas); č) sat-dva dnevno; ć) više sati svakoga dana;

d) nešto drugo

3. 3. Pitanje br. 3 bilo je pitanje zatvorenog tipa (sa mogućnošću višestrukog odgovora) kojima smo želeli da otkrijemo na koji način studenti unapređuju poznavanje srpskog jezika (i kao maternjeg i kao nematernjeg). Ukupno 51\% svih ispitanika (v. Tabela 5) odgovorilo je da sa tim ciljem koristi internet i druge elektronske izvore, čime je potvrđena $\mathrm{H} 4: \mathrm{Da}$ bi unapredili poznavanje srpskog jezika, studenti najčešće koriste internet i druge elektronske izvore. Isto je i kada je reč o studentima kojima je maternji jezik srpski (osnovne studije: $14 \%$ odgovora, master studije 30\% odgovora, v. Tabela 5), čime je potvrđena H4(a): Studenti kojima je srpski jezik maternji jezik za unapređivanje svoga jezika najčešće koriste internet i druge elektronske izvore. Studenti koji nastavu slušaju na rumunskom nastavnom jeziku isto postupaju, dok studenti koji nastavu slušaju na romskom jeziku smatraju da im je formalno obrazovanje dovoljno (3\%), kao i da ne misle o tome posebno, da se to događa usput (3\%). Nijedan student kojem je srpski jezik nematernji nije odgovorio da pohađa kurseve iz srpskog jezika van nastave, te $\mathrm{H} 4$ (b): Studenti kojima je srpski jezik nematernji jezik pohađaju van nastave specijalizovane kurseve iz srpskog jezika ostaje nepotvrđena. 
Tabela 5. Mogućnosti unapređivanja poznavanja srpskoga jezika iz vizure studenata

\begin{tabular}{|l|l|l|l|l|l|}
\hline Pitanje br. 3 & OSS & OSSRUM & OSSROM & MSS & Ukupno \\
& 30 & $10^{*}$ & 10 & $50^{*}$ & $100^{*}$ \\
\hline & a) $2 \%$ & a) $2 \%$ & a) $3 \%$ & a) $1 \%$ & a) $8 \%$ \\
Na koji način & b) $2 \%$ & b) $0 \%$ & b) $0 \%$ & b) $0 \%$ & b) $2 \%$ \\
unapređujete & c) $14 \%$ & c) $6 \%$ & c) $1 \%$ & c) $30 \%$ & c) $51 \%$ \\
poznavanje & č) $2 \%$ & č) $1 \%$ & č) $1 \%$ & c) $5 \%$ & č) $9 \%$ \\
srpskoga & ć) $1 \%$ & ć) $2 \% *$ & ć) $2 \%$ & ć) $9 \%$ & ć) $14 \%$ \\
jezika? & d) $5 \%$ & d) $0 \%$ & d) $0 \%$ & d) $8 \%$ & d) $13 \%$ \\
& dž) $4 \%$ & dž) $2 \%$ & dž) $3 \%$ & ď̌) $5 \%$ & dž) $14 \%$ \\
& & & & & \\
& & & & & $111 \% 5$ \\
\hline
\end{tabular}

Legenda:

a) Formalno obrazovanje je dovoljno;

b) Van nastave pohađam specijalizovane kurseve iz srpskog jezika;

c) Pomoću interneta i drugih elektronskih izvora;

č) Putem vršnjačke edukacije;

ć) Uglavnom sam samouk(a);

d) Na neki drugi način;

dž) Ne mislim o tome, to se događa usput.

3.4. Na pitanje broj 4 - zasnovano na hipotezama: Šta bi bilo kada bi danas „Pravopis srpskoga jezika" (2010) ${ }^{6}$ [u daljem tekstu: Pravopis] progovorio? O čemu bi nam on pričao? - studenti su imali zadatak da daju kreativne odgovore. Pregled dominantnih tema/ideja (v. Tabela 6) o kojima su studenti pisali pokazuje da bi prema mišljenju studenata u toj zamišljenoj situaciji Pravopis pre svega pričao o nepoštovanju ortografske norme i pismenosti uopšte $(13 \%$ svih odgovora), o pravopisnim greškama (12\%), o značaju negovanja kulture govora i lepih reči (11\%), te o pravilima u pojedinačnim pravopisnim oblastima (9\%), kao i o istoriji nastanka i razvoja pravopisa (8\%). Indikativni su sledeći odgovori studenata:

Kad bi Pravopis progovorio, rekao bi da mu nije do života zbog svakodnevnih ogrešenja o pravopisnu normu. / Imamo sreće zato što Pravopis nema osećanja, inače bi bilo puno suza i razočaranja. / Smejao bi se do suza./ Pričao bi nam o tome kako smo ga dosta zapustili./ Tražio bi da ne napravimo od njega „engleza” ili „„̌vabu”, jer mnogo više vredi ovako „domaći”. / Kada bi Pravopis progovorio, pričao bi mi kako se on (Pravopis) rodio, kako je on kroz vreme putovao i sleteo u sadašnjost.

$\mathrm{Na}$ osnovu analize odgovora studenata ne možemo reći da je $\mathrm{H}_{5}$ : Studenti imaju pomirljiv (egalistički) stav kada je reč o poštovanju pravopisnih pravila u srpskom jeziku potvrđena. Međutim, odgovori studenata nisu u visokoj korelaciji s komotnošću s kojom se odnosimo prema pravopisu, pa ni prema drugim oblicima pismenosti. Na svesnom nivou, kako vidimo, zna se vrednost pravopisa, ali se on, izgleda, ,uzima zdravo za gotovo”, pravopis se poštuje parcijalno, pristup je često površan itd. (up. Veljković Stanković i Đorđev, 2018b: 17). U prilog rečenom stoji i odgovor studenta, pisan iz ugla samoga Pravopisa, koji govori o slaboj ili nedovoljnoj primeni pravopisnih pravila u svakodnevnim situacijama: „Jao, pa koja je moja svrha [svrha Pravopisa], ako me niko ne čita i upotrebljava, već svako piše i govori kako mu je volja."

\footnotetext{
${ }^{5}$ Studenti su imali mogućnost višestrukog odgovora. Ukupno je deset ispitanika zaokružilo po dva odgovora; višestruke odgovore davali su uglavnom studenti master studija, kao i svega dva studenta osnovnih studija kojima srpski jezik nije maternji već rumunski jezik.

${ }^{6}$ Štampano ćirilicom.
} 
Kako pokazuje Tabela 6 studenti (osnovnih studija) kojima je maternji jezik srpski jezik ističu važnost negovanja kulture govora i upotrebe lepih reči, kao i studenti master studija, s tim da odgovori studenata drugog nivoa studija pokazuju da se interesuju i za istorijski aspekt ortografske norme, čime je $\mathrm{H}_{5}(\mathrm{a})$ : Studenti kojima je maternji jezik srpski jezik ističu važnost negovanja kulture govora i upotrebe lepih reči - potvrđena. Studenti kojima je srpski nematernji jezik fokusirani su na pravopisne greške (Romi), kao i pojedinačne pravopisne oblasti i uticaj stranih normi na našu pravopisnu normu (Rumuni), čime je delimično potvrđena $\mathrm{H}_{5}(\mathrm{~b})$ : Studenti kojima je srpski nematernji jezik ističu problem (mnoštva) pravopisnih grešaka u pismenom izražavanju.

Tabela 6. Stavovi studenata o poštovanju pravopisnih pravila u srpskom jeziku

\section{Pitanje br. 4}

Šta bi bilo kada bi Pravopis danas progovorio? O čemu bi nam on pričao?

Pregled dominantnih ideja/ tema

Nepoštovanje ortografske norme pismenosti uopšte

Pravopisne greške

Značaj negovanja kulture govora i

lepih reči

Pojedinačne pravopisne oblasti

(teme)

Istorija pravopisa

Odnos mladih prema pravopisu

Zanemarivanje nastave pravopisa

Uticaj IKT-a i digitalizacija

Značaj čitanja i celoživotnog učenja

Uticaj stranih normi

Izmene i dopune pravopisne norme

Dubletna pravopisna rešenja

\section{Razno}

$\mathrm{BO}$

Ukupno odgovora

Ukupno

\begin{tabular}{c|c} 
OSS & OSSRUM \\
30 & 10 \\
& \\
& \\
\hline 1 & 1
\end{tabular}

1

3

3

6

1

0

\begin{tabular}{l|l}
2 & 2 \\
\hline
\end{tabular}

\begin{tabular}{|c|c|c|c|c|}
\hline 2 & 0 & 0 & 6 & $8 \%$ \\
\hline 1 & 0 & 0 & 4 & $5 \%$ \\
\hline 1 & 1 & 0 & 2 & $4 \%$ \\
\hline 1 & 1 & 0 & 2 & $4 \%$ \\
\hline 1 & 0 & 0 & 3 & $4 \%$ \\
\hline 0 & 2 & 0 & 0 & $3 \%$ \\
\hline 0 & 0 & 0 & 1 & $1 \%$ \\
\hline 5 & 1 & 0 & 1 & $1 \%$ \\
\hline $80 \%$ & 1 & 2 & 6 & $13 \%$ \\
\hline$(24)$ & $90 \%$ & $80 \%$ & $94 \%$ & $88 \%$ \\
\hline $100 \%$ & $19)$ & $(8)$ & $(47)$ & $(88)$ \\
\hline & $100 \%$ & $100 \%$ & $100 \%$ & $100 \%$ \\
\hline
\end{tabular}

3.5. Pitanje br. 5 u anketnom upitniku bilo je otvorenog tipa i zahtevalo je od ispitanika da ukažu, prema njihovom mišljenju, na mogućnosti unapređivanja nastave srpskoga jezika na visokoškolskim ustanovama (koje ih realizuju) ${ }^{7}$. Najveći broj anketiranih studenata (v. Tabela 7) smatra da je za unapređivanje nastave srpskoga jezika presudna uloga kvantiteta (više predavanja, vežbi - $11 \%$ svih odgovora, više seminara i radionica - $9 \%$ svih odgovora), čime je potvrđena H6: Kada je reč o mogućnostima unapređivanja visokoškolske nastave srpskoga jezika, studenti smatraju da je presudna uloga kvantiteta, odnosno da nastavi srpskog jezika treba posvetiti više časova predavanja, vežbi, ali i seminara, kao i dopunskog rada.

\footnotetext{
${ }^{7}$ Značajno bi bilo da se predmet Srpski jezik uvede u sve visokoškolske ustanove, čime bi se postavili razložno i funkcionalno viši zahtevi u pogledu razvijenosti govorne kulture, bez koje ne može biti ni ozbiljnijeg napretka u struci, pa ni napretka društva u celini. Tek promenom ovih važnih parametara može se uticati i na poboljšanje kvaliteta nastave u celini, pa i na podizanje ugleda svih koji se bave vaspitnim i obrazovnim radom u školama.
} 
Tabela 7. Mogućnosti unapređivanja nastave srpskoga jezika iz perspektive studenata

\begin{tabular}{|c|c|c|c|c|c|}
\hline $\begin{array}{l}\text { Pitanje br. } 5 \text { Nastava srpskog jezika na } \\
\text { visokim školama mogla bi se unaprediti na } \\
\text { sledeći način (dopunite): }\end{array}$ & $\begin{array}{l}\text { OSS } \\
30\end{array}$ & $\begin{array}{l}\text { OSSRUM } \\
10\end{array}$ & $\begin{array}{l}\text { OSSROM } \\
10\end{array}$ & $\begin{array}{l}\text { MSS } \\
50\end{array}$ & $\begin{array}{l}\text { Ukupno } \\
100\end{array}$ \\
\hline $\begin{array}{l}\text { - } \quad \text { većim fondom časova i jezičkih } \\
\text { nastavnih predmeta }\end{array}$ & 2 & 0 & 1 & 8 & $11 \%$ \\
\hline - $\quad$ seminarima i radionicama & 1 & 0 & 0 & 8 & $9 \%$ \\
\hline čitanjem & 2 & 0 & 0 & 7 & $9 \%$ \\
\hline $\begin{array}{l}\text { - } \quad \text { povećanom samostalnom aktivnošću } \\
\text { studenata (prezentacije) }\end{array}$ & 4 & 0 & 0 & 3 & $7 \%$ \\
\hline $\begin{array}{l}\text { - } \quad \text { uvođenjem više svakodnevnih primera } \\
\text { (up. komunikativni pristup) }\end{array}$ & 1 & 0 & 0 & 6 & $7 \%$ \\
\hline - $\quad$ primenom igre i dramskim pristupom & 3 & 0 & 0 & 4 & $7 \%$ \\
\hline - $\quad$ upotrebom IKT-a & 1 & 3 & 0 & 0 & $4 \%$ \\
\hline $\begin{array}{l}\text { - većom interakcijom i komunikacijom na } \\
\text { predavanjima }\end{array}$ & 0 & 1 & 0 & 3 & $4 \%$ \\
\hline - $\quad$ projektnim aktivnostima & 1 & 0 & 0 & 2 & $3 \%$ \\
\hline $\begin{array}{l}\text { - } \quad \text { (periodičnim) testiranjem i radom na } \\
\text { tekstu }\end{array}$ & 1 & 0 & 1 & 0 & $2 \%$ \\
\hline - $\quad$ ne treba ništa unapređivati & 0 & 2 & 0 & 0 & $2 \%$ \\
\hline Razno & 0 & 1 & 2 & 3 & $6 \%$ \\
\hline $\mathrm{BO}$ & 14 & 3 & 6 & 6 & $29 \%$ \\
\hline Ukupno odgovora & $\begin{array}{l}53 \% \\
(16)\end{array}$ & $\begin{array}{l}70 \% \\
(7)\end{array}$ & $\begin{array}{l}40 \% \\
(4)\end{array}$ & $\begin{array}{l}88 \% \\
(44)\end{array}$ & $\begin{array}{l}71 \% \\
(71)\end{array}$ \\
\hline Ukupno & $100 \%$ & $100 \%$ & $100 \%$ & $100 \%$ & $100 \%$ \\
\hline
\end{tabular}

Ukupno $9 \%$ anketiranih studenata ističu važnost čitanja, što je afirmativno. Važnost navike čitanja uvek treba posebno isticati, jer se pismeno izražavanje unapređuje dugotrajnim čitanjem i pažljivim slušanjem, dok sam proces pisanja treba da predstavlja izraz unutrašnje potrebe i nadahnuća. Čitanje, kao intelektualno podsticajan proces, treba da svestrano pobuđuje pažnju, i to ne samo sadržajem napisanog (saopštenog), već i sposobnošću prepoznavanja kompozicionih celina, stilskih postupaka, a takođe i zapažanjem (ne)poštovanja ortografske norme, čija pravilna primena $\mathrm{i}$ te kako doprinosi valjanom uobličavanju, preciznosti i jasnoći verbalnog sadržaja. Metafora RAZUMEVANJE JE VIĐENJE (isp. Klikovac, 2004: 52; Lakoff \& Johnson, 2003: 103) ovde ima veliki značaj, jer dobro znanje, npr. pravopisa ne proverava se samo pisanjem, već i čitanjem i osposobljenošću učenika za precizno uočavanje grešaka i valjanu korekciju (svog ili tuđeg) teksta. Nažalost, narastajuća kriza čitanja mlade sve više odvaja od pisanog govora, a time i od vizuelne percepcije teksta u kome je valjano (nekad i nedovoljno) poštovana pravopisna norma.

Kako pokazuje Tabela 7, studenti master studija kojima je srpski jezik maternji jezik najčešće unapređivanje nastave srpskoga jezika vide u povećanom broju časova nastave, seminarima i radionicama, dok studenti osnovnih studije ističu važnost povećane samostalne aktivnosti, tako da možemo konstatovati da je H6(a): Studenti kojima je srpski jezik maternji jezik najčešće unapređivanje nastave srpskoga jezika vide u povećanom broju časova nastave, seminara $i$ radionica - delimično potvrđena. Isto važi i za hipotezu H6(b): Studenti kojima je srpski jezik nematernji jezik najčešće unapređivanje nastave srpskog jezika vide u intenzivnijoj upotrebi informaciono-komunikacionih tehnologija, jer, kako pokazuje Tabela 7, studenti koji pohađaju nastavu na rumunskom jeziku za unapređivanje nastave srpskoga jezika predlažu upotrebu IKT-a, a učestalije testiranje, rad na tekstu, akcentuju studenti na romskom nastavnom jeziku. 


\section{Zaključak}

Iz hipoteza potvrđenih ovim istraživanjem zaključujemo da se srpski jezik iz perspektive studenata doživljava kao kompleksan pojam. Studenti srpski jezik najčešće poimaju preko izvornog domena nedovoljno istraženog i nepoznatog prostora. Izbor ovog izvornog domena ukazuje na to da su studenti svesni vlastite nesigurnosti prilikom primene znanja iz srpskog jezika, kao i da postoji određena odbojnost i zazor pred pravilima koje uspešno usmeno i pismeno izražavanje na ovom jeziku podrazumeva. Aktivnostima eksplicitno usmerenim na usavršavanje/negovanje srpskoga jezika studenti posvećuju dnevno od 15 minuta do 45 minuta - isto toliko i učenju stranog jezika - a da bi unapredili poznavanje ovog jezika, studenti najčešće koriste internet i druge elektronske izvore. Studenti kojima je maternji jezik srpski jezik ističu važnost negovanja kulture govora i upotrebe lepih reči, a većina studenata kojima je srpski nematernji jezik ističu problem (mnoštva) pravopisnih grešaka u pismenom izražavanju. Kada je reč o mogućnostima unapređivanja nastave srpskoga jezika, studenti smatraju da je presudna uloga kvantiteta, odnosno da nastavi srpskoga jezika treba posvetiti više časova predavanja, vežbi (u visokoškolskim ustanovama koje realizuju nastavu ovoga predmeta), kao i seminara i vannastavnog dopunskog rada. Ovde izdvojena, ali i druga zapažanja izneta u radu, ocrtala su polja budućega rada kada je reč o nastavi srpskoga jezika u multinacionalnoj studentskoj zajednici:

- Vladajući koncept nedovoljno istraženog i nepoznatog prostora valja, primenom teorijsko-metodološke aparature kognitivne lingvistike, ili kojim god drugim načinom, modifikovati u koncept srpskoga jezika kao važnog i vrednog entiteta, pogotovo za njegove govornike. Rečju, valja negovati jedan afirmativan odnos prema maternjem i jeziku sredine. Da bi se to postiglo, treba uvežbati primenu znanja (up. funkcionalnost) iz srpskog jezika, te sistematskim i kontinuiranim vežbanjima ukinuti odbojnost i zazor pred pravilima koje uspešno usmeno i pismeno izražavanje na ovom jeziku podrazumeva.

- S obzirom na to da studenti najčešće posežu za internetom i elektronskim izvorima kada imaju jezičkih nedoumica, sva preimućstva IKT-a treba iskoristiti u nastavnom procesu. U tom smislu, treba nastavnike i saradnike obučiti u valjanoj primeni ovih elektronskih alata i uvesti elektronske platforme u nastavu, kao što su Mudl (engl. Moodle), Trelo (Trello) i sl. Uopšteno govoreći, više pažnje treba posvetiti unapređivanju digitalne pismenosti i digitalne kulture zaposlenih u obrazovanju.

- Treba omogućiti više časova predavanja, vežbi, ali i seminara, kao i dopunskog vannastavnog rada, produžujući tako vreme koje posvećujemo usavršavanju i negovanju srpskoga jezika. (Ono ne može biti isto kao vreme koje provodimo učeći neki strani jezik.)

- Budući da nisu potvrđene (delimično ili u celosti) hipoteze koje pretpostavljaju komunikativnu ulogu jezika, a, s druge strane, studenti zahtevaju rad na primerima iz svakodnevnih životnih situacija, u nastavnoj praksi treba (intenzivnije) primenjivati i komunikativni pristup.

- Za studente kojima je srpski jezik nematernji jezik valja osmisliti i specijalizovane kurseve iz srpskog jezika i sprovesti u praksi. Plan i program takvih kurseva mogli bi da kreiraju studenti-polaznici kurseva sa nastavnicima-mentorima, a imajući u vidu sopstvena interesovanja i zahteve multikulturalne sredine. Moguća je realizacija projektne nastave, integrativnog pristupa, ali i studija kratkoga ciklusa.

- $\quad$ Pregled dominantnih tema dobijenih u odgovorima studenata na pitanje br. 4 pokazuju da su studenti svesni problema nepoštovanja ortografske norme i pismenosti sa kojima se susreću svakodnevno, pravopisnih grešaka, značaja negovanja kulture govora i upotrebe lepih reči, ali da nedostaje reakcije na takvo zatečeno stanje - pravopis se 
poštuje parcijalno, pristup je često površan... Stoga bi bilo korisno pooštriti kriterijume kada je reč o pravopisnim uzusima prilikom izrada seminarskih, a posebno završnih radova. Ono što se nekada podrazumevalo, a to je poštovanje normi - sada je izgleda postala raritetna pojava.

Istraživanjem prezentovanim u ovom radu svakako nisu obuhvaćena sva pitanja i problemi koji se mogu javiti u nastavnom radu sa studentima kojima je srpski jezik maternji, kao i sa studentima kojima je srpski jezik nematernji jezik (v. npr. Đorđev i Raić, 2018: 55-69), ali ono jeste skiciralo neka od polja u kojima bi trebalo unaprediti nastavu srpskoga jezika, čime je potvrđena i naša polazna hipoteza. U perspektivi, valjalo bi, pre svega na obuhvatnijem uzorku romskih i rumunskih studenata, poduzeti šira istraživanja, te otkriti i klasifikovati probleme ( greške) u primeni normi srpskoga jezika kao jezika sredine kako u usmenom tako i u pismenom izražavanju ovih studenata. Nadamo se da će ovaj rad u takvim i sličnim poduhvatima imati pokretačku ulogu.

\section{Literatura:}

Antović, M. (2007). Teorija optimalnosti i teorija metafore u svetlu muzičke i jezičke kompetencije. Doktorska disertacija. Univerzitet u Nišu, Filozofski fakultet. Preuzeto sa:

http://nardus.mpn.gov.rs/bitstream/handle/123456789/4003/Disertacija.pdf?sequenc $\mathrm{e}=1$ \&isAllowed $=y$ (10. 8. 2019). (štampano ćirilicom)

Brborić, V. (2011). Pravopis i škola. Beograd: Čigoja štampa. (štampano ćirilicom)

Brendt, E. (2008). Intersections and diverging paths: Conceptual patterns on learning in English and Japanese. Metaphors for Learning: Cross-cultural Perspectives, 73-102.

Bugarski, R. (2003). Uvod u opštu lingvistiku. Beograd: Čigoja, XX vek.

Caballero, R. (2006). Journey metaphors in foreign language teaching-learning: Ways of travelling/learning in multimedia environments. Mélanges CRAPEL, 28, 201-211.

Cook-Sather, A. (2003). Movement of mind: The matrix, metaphors, and reimagining education. Teacher College Records, 105, 946-977.

Dragićević, R. (2006). Srpski jezik i kultura izražavanja za V razred osnovne škole. Beograd: Zavod za udžbenike i nastavna sredstva. (štampano ćirilicom)

Đorđev, I. (2014). Possible applications of conceptual metaphors (cognitive approach) to improve orthography teaching. Research in Pedagogy, 4/1, 130-143.

Đorđev, I. (2019). Literacy in the 21st century from the perception of pupils of secondary schools. Research in pedagogy, 9/2, 127-142.

Đorđev, I., Kelemen Milojević, Lj. (2017). Konceptualizacija dramskog metoda i njene implikacije u vaspitno-obrazovnoj praksi. Metodička praksa, 13/2, 275-284. (štampano ćirilicom)

Đorđev, I., Raić, S. (2018). Konceptualizacija komunikacije u multinacionalnoj studentskoj zajednici. U: T. Nedimović, i I. Đorđev (ur.), Komunikacija u multikulturalnoj sredini $i$ vaspitno-obrazovnom radu. Vršac: Visoka škola strukovnih studija za vaspitače „Mihailo Palov”, 55-69. (štampano ćirilicom)

Farjami, H. (2012). EFL Students Images and Metaphors of Grammar Learning. Iranian Journal of Applied Linguistics (IJAL), 15(1), 19-41.

Gojkov, G. (1995). Kognitivni stil u didaktici. Vršac: Viša škola za obrazovanje vaspitača.

Gojkov, G. (2009). Didaktika i metakognicija. Vršac: Visoka škola strukovnih studija za obrazovanje vaspitača ,Mihailo Palov”. 
Informator za studente. Knjiga predmeta. Preuzeto sa: https://uskolavrsac.edu.rs/info/wpcontent/uploads/2014/11/Knjiga-predmeta-VDPU-za-19-20.pdf (3. 4. 2020).

Kesen, A. (2010). Turkish Efl Learners'metaphors with Respect to English Language Coursebooks. Novitas-ROYAL, 4(1).

Klikovac, D. (2004). Metafore u mišljenju i jeziku. Beograd: Čigoja štampa.

Klikovac, D. (2018). Srpski jezik u svetlu kognitivne lingvistike. Beograd: Čigoja štampa. (štampano ćirilicom)

Kovač Rac, E. i Halupka Rešetar, S. (2017). Stavovi prema srpskom jeziku među učenicima vojvođanskih srednjih škola na mađarskom nastavnom jeziku. Nasleđe, 38, 141-161. (štampano ćirilicom)

Krajišnik, V. i Strižak, N. (2018). Srpski kao strani i srpski kao nematernji jezik - sličnosti i razlike. U: Lj. Bajić, J. Ginić i N. Stanković Šošo (ur.), Aktuelni teorijsko-metodološki problemi proučavanja i nastave slovenskih jezika, književnosti i kultura : zbornik radova. Beograd: Filološki fakultet, 181-193.; https://doi.org/10.18485/mks_knsjkk.2017.ch12 (3. 4. 2020). (štampano ćirilicom)

Lakoff, G. (1993). The contemporary theory of metaphor. In: Metaphor and Thought, Cambrige, CUP, 202-251.

Lakoff, G., Espenson, J., Scwartz, A. ${ }^{2}(1991)$. Master Metaphor List. Berkeley: University of California.

Lakoff, G., Johnson, M. (1980, 2003). Metaphors we live by. Chicago: The University of Chicago Press.

Martinez, M., Sauleda, N., Huber, G. L. (2001). Metaphors as Blueprints of Thinking about Teaching and Lerning. Teaching and Teacher Education 17, 965-977.

Nagamine, T. (2012). A metaphor analysis of preservice EFL teachers' beliefs regarding professional identity. The Asian EFL Journal, 14(2), 141-171.

Nikolić, M. ( $\left.{ }^{4} 2006\right)$. Metodika nastave srpskoga jezika i književnosti. Beograd: Zavod za udžbenike i nastavna sredstva. (štampano ćirilicom)

Paunović, T. (2009). Sociolingvistički pogled u susedovo dvorište: stavovi prema jezičkim varijetetima. Radovi Filozofskog fakulteta, 11/1, 77-99.

Pravopis srpskoga jezika. Pravila i njihovi osnovi. Rečnik uz pravopis (izmenjeno i dopunjeno ekavsko izdanje) (2010). Novi Sad: Matica srpska. (štampano ćirilicom)

Radić Bojanić, B. (2012). Usvajanje metaforičkih izraza iz domena vremenskih prilika. U: M. Krstić (ur.), Zbornik radova Filozofskog fakulteta u Prištini, 42/1, 265-277. Preuzeto sa: https://scindeks-clanci.ceon.rs/data/pdf/0354-3293/2012/0354-32931201265R.pdf (4. 4. 2020). (štampano ćirilicom)

Veljković Stanković, D. (2008). Kognitivni pristup evalutivnim tvorenicama i njegova primena u nastavi srpskog jezika. Naučni sastanak slavista u Vukove dane, 37/1, 497-510. (štampano ćirilicom)

Veljković Stanković, D. (2009). Metafore o nastavi, nastavnicima i učenju maternjeg jezika. Naučni sastanak slavista u Vukove dane, 38/3, 103-117. (štampano ćirilicom)

Veljković Stanković, D. (2013). Mogućnosti primene kognitivnog pristupa u nastavi srpskoga jezika (na primeru obrade gramatičke kategorije glagolskog vida). Naučni sastanak slavista u Vukove dane, 42/3, 85-113. (štampano ćirilicom)

Veljković Stanković, D. (2018a). Čovek u velikom krugu postojanja - kognitivni pristup u radu lingvističke sekcije. U: Lj. Bajić, J. Ginić i N. Šošo (ur.), Zbornik Komisije za nastavu slovenskih jezika i književnosti, 259-274. (štampano ćirilicom)

Veljković Stanković, D. (2018b). Kako mislimo reči. Prilozi proučavanju kognitivnih aspekata srpske leksike. Beograd: Jasen. (štampano ćirilicom) 
Veljković Stanković, D., Đorđev, I. (2018a). Mogućnosti primene kognitivnog pristupa u nastavi pravopisa. U: S. Gudurić, B. Radić-Bojanić (ur.), Zbornik radova sa Međunarodnog naučnog skupa „Jezici i kulture u vremenu i prostoru 7”, Novi Sad: Filozofski fakultet, 41-53. (Štampano ćirilicom)

Veljković Stanković, D., Đorđev, I. (2018b). Pismenost novog doba iz perspektive budućih vaspitača i nastavnika. Primenjena lingvistika, 19, 7-22. (štampano ćirilicom)

\section{Biografska beleška}

Ivana Đorđev je doktor filoloških nauka (naučna oblast: Metodika nastave srpskoga jezika, Srpski jezik). Radila je deset godina kao profesor srpskog jezika i književnosti u gimnaziji. Dobitnica je nagrade Zavoda za unapređivanje obrazovanja i vaspitanja (2012), dok joj je uspešna priprema učenika za takmičenja iz oblasti srpskog jezika i kulture izražavanja donela više zahvalnica Društva za srpski jezik i književnost Srbije, Vukove zadužbine i Ministarstva prosvete Republike Srbije; 2019. godine uvrštena je u 1000 stvaralaca R Srbije („Лексикон стваралаца у предуниверзитетском образовању", Beograd: Klett). Od 2013. godine zaposlena je na Visokoj školi strukovnih studija za vaspitače „Mihailo Palov” u Vršcu, najpre kao predavač, a od 2016. godine kao profesor strukovnih studija. Do sada je u autorstvu ili koautorstvu objavila više od pedeset naučnih i stručnih radova iz oblasti savremenog srpskog jezika, lingvistike i metodike nastave, zapažene prikaze knjiga, kao i više različitih (monografskih) bibliografskih publikacija. Aktivno učestvuje na domaćim i međunarodnim projektima, stručnim i naučnim skupovima i konferencijama, pretežno međunarodnog karaktera. Recenzent je radova iz društveno-humanističkih nauka nekoliko časopisa (na srpskom i engleskom jeziku); autor, koautor i realizator više programa stalnog stručnog usavršavanja nastavnika, vaspitača i stručnih saradnika. Sve relevantne informacije u vezi sa naučnim radom $i$ publikacijama dostupne su na adresi: http://www.uskolavrsac.edu.rs/profesori/dr-djordjev-ivana/.

Eldena Stanić je specijalista za pripremni predškolski program, student druge godine master studija na Visokoj školi strukovnih studija za vaspitače „Mihailo Palov” u Vršcu. Od 2015. godine zaposlena je u istoj školi kao saradnik u nastavi u užim pedagoškim oblastima (za predmete: Romski jezik; Književnost za decu na romskom jeziku; Metodika razvoja govora 1 i 2 na romskom jeziku). Aktivno učestvuje na domaćim i međunarodnim projektima. Član je umetničkog društva „,VAU ARS” i predsednik omladinske organizacije „Rromane Čhavrra Rromano Futuro", koja se bavi podsticanjem obrazovanja, problemima mladih Romkinja i Roma i suzbijanjem diskriminacije. Učesnik je i organizator aktivnosti Erasmus+ projekata. 